\title{
NEW SERBIAN INTEGRATION CHALLENGE: RUSSIAN AND/OR CHINESE EURASIANISM
}

\begin{abstract}
Milomir Stepić ${ }^{1}$
Abstract: The political, economic, and security supranational organizations of the West are in an obvious crisis and downward trajectory, although still very powerful. From the point of view of Serbian national interests, it is risky for the proclaimed and practical integration orientation to remain "on the path without an alternative" following that direction. In the new conditions of multipolarization of the world, this orientation has to be less dogmatic and follow the rapid changes not only in the hierarchy of "big players" but also their interests in the Balkans. Primarily, this refers to the increasingly influential Russia and China, which have different, though not incompatible concepts of Eurasianism. Their common strategic goal is to push the USA domination from the "largest landmass on the planet". In that context, it is geopolitically logical that Russia and China perceive the future position of the Balkans and the role of the Serbian factor completely differently from the personifications of the West - the EU and NATO. This does not mean that Russian and Chinese interests are in the lasting agreement, and their rivalry on the "chains of the world" (Catena Mundi) is not possible if/once they push away the still leading world power to the other side of the Atlantic. The long-term future of the "Serbian pebble" will depend on the ability to fit adequately into that future complicated integrative "geopolitical mosaic".

Keywords: geopolitics, integrations, rivalry, alliance, Serbian factor, Russia, China.
\end{abstract}

${ }^{1}$ Institute for Political Studies, Svetozara Markovića 36, Belgrade, e-mail: milomir.stepic@gmail.com 


\section{Transfer of global power and Serbian integration dogma}

Serbia's commitment to integration has never been tested in a referendum. Ending the phase of political-territorial functioning, first in the monarchist and then Titoist Yugoslav supranational state after its violent disintegration, the Serbian corps was immediately imposed with involvement into the integrational creations of the West as its only option primarily in the EU, and in a specific way in NATO. Such an orientation has been almost implicit since the post-Cold War European East was in the process of disintegration, geopolitical regression and economic collapse, and the triumphalist West was at the peak of power and in the momentum of spatial expansion, which included the post-Yugoslav part of the Balkans. Consequently, the postmodern, neoliberal understanding of integration at that time, 'implies less the merging of parts into a whole and the increase of internal cohesion, but mostly the notion acquires the geopolitical connotation of territorial expansion. Integration has become a seemingly more benign variant and a "politically correct" substitute for traditional actions of (un) armed aggression, (in) direct occupation, (neo) colonialism, and (neo) imperial domination' (Степић, 2014a, p.154).

In the meantime, the world has fundamentally changed and is increasingly gaining completely new contours in all its forms. They mostly stem from the epochal translation of geopolitical and geoeconomic power from the Atlantic regions of America and Europe to the Indo-Pacific region and the Heartland of Eurasia, i.e., from the USA and the EU to China, Russia, India, the Far East "tigers". Without any doubt, the so-called unipolar moment has irrevocably passed, and the absolute American hegemony in the last decade of the 20th and the first decade of the 21st century gave way to relative unipolarism (Stepić, 2017, p. 23). According to the cumulative indicator resulting from numerous factors of "tangible" and "intangible power", the USA is still the leading actor in world affairs, but its power is increasingly crumbling. The USA is no longer an unattainable hyperpower as it seemed at the turn of the millennium (for example, at the time of the aggression on the FRY in 1999), and the distance in relation to its runnersup, especially China, is rapidly decreasing. Before our eyes, a true multipolarism is emerging in all its complexity and various manifestations, which tends to grow into a somewhat balanced neo-bipolarism. In this 'new cold 
war' (Пандуревић, 2018), which can be more precisely and essentially called the 'continuity of the cold war' (Трифковић, 2017), the USA can gradually become a weaker side if it fails to try to confront Eurasian giants.

The former imposition of USA narcissistic self-knowledge about the socalled necessary nation and its own Messianic role on the whole world now exists less and less even on the internal plane of "reality facing". The systemic fragility of the Empire's core is indicated by the disorganization and conflict that are growing every day and in different forms. They are less and less an exception and incident, and more and more a permanent condition that grows into a chronic social pathology. This was somewhat witnessed in the explosion of riots and anarchy caused by deep contradictions, whose immediate cause was the death of a controversial African-American due to police torture. Another morbid indicator was the pandemic of the COVID 19 virus, which officially infected over 5.5 million people in the United States by mid-August 2020 and claimed more than 172,000 lives, (https://www.worldometers.info/coronavirus/ country/us/), i.e., $22.5 \%$ of the total death toll in the world, with the egoistic reaction of a large number of USA federal states. Thus, there were sarcastic proposals in the public that the global leader should be given a new name instead of the United States of America - Divided States of America (Над, 2020, p. 53). Therefore, the number of countries considering the USA for an example of reputation and reason for voluntary compliance to Westernization, as an American variant of globalization, is increasingly decreasing. Also, the instruments of Pax Americana - primarily NATO as a military-security integration, and the EU as an economic-political Atlantic integration, have slowly ceased to be reasons for such belief.

Despite the obvious declinism of the West, the official Serbian integration orientation masochistically stays directly on the European path, and indirectly on the North Atlantic ship. Such a (geo) politics is even more absurd given the recent experience - NATO under the leadership of the USA acted biasedly anti-Serbian during the break-up of the SFRY, actively participating in air strikes on the Republic of Serbian Krajina and the Republic of Srpska 1994-1995, carrying out open aggression against the Federal Republic of Yugoslavia (mostly Serbia) in 1999, while, at the same time, the EU favored Serbian rivals and directly applied harsh economic sanctions, used political pressure and waged a real propaganda war against the Serbian people and state. Besides, both NATO and the EU - mostly 
coordinatedly and sometimes each in their own way - are still directly helping the secessionist ambitions of the Albanian national minority and trying by all means to separate the Kosovo-Metohija part of Serbia. All this was not a sufficient reason to reduce the country's economic and trade dependence on the West, slowly, gradually and with minimal negative consequences over a relatively long period of 2-3 decades, and thus at least partially blunt its "blackmailing capacity" which several generations of Serbian nomenclatures have used as an alibi. For several years now, the conditions for foreign policy reorientation have been improving because the alternative appears in the East.

\section{The world, Europe, the Balkans: less Atlanticism, more Eurasianism}

For the entire half of the millennium - from Columbus and the so-called Great geographical discoveries until the second decade of the 21st century - the world was shaped on the foundations of thalassocratic, Atlanticism supremacy. Current turbulent events and processes testify to fundamental, epochal, historically important changes and the end of the primacy of the westernized part of the world. Analogous to the indicators of the beginnings of the decline of earlier empires, there are undeniable indicators of the downward trajectory of the current outgoing global Empire:

- the increasingly visible slippage of American society into decadence, the transformation of identity, indifference towards the state and the loss of national "passion";

- the weakening of internal cohesion and harmony, which was unquestionable during the rise and peak, despite the national, religious, racial and other heterogeneity of the USA;

- an unbearable level of the external overstrain that results in America's inability to realize its self-proclaimed "vital national interest" in every corner of the Planet;

- problems of retaining influence in the strategically most important regions, especially in Europe as a 'stepping stone for progressive expansion' and 'America's most important geopolitical bridgehead' on the Eurasian mega-mainland (Bžežinski, 2001, p. 57); 
- increasing disloyalty of the most important (post) modern vassals, where an indicative example is the traditionally tellurocratic, centrally positioned and economically strongest European country Germany, to which the USA seeks to prevent energy security (Nord Stream 2) even with the threat of economic sanctions;

- the inability to prevent the "uniting of barbarians" - primarily the strongest, China and Russia - and to resist their joint anti-American (anti-Western) action;

- increasing difficulties in keeping client-countries in its sphere of interest and preventing them from being gravitationally drawn into the orbit of rival forces.

The former unipolar advance of Atlanticism in all directions has been largely stopped and forced to "burrow", and on some "fronts" to be on the defensive. This is unmistakably recognized by the current state and functioning of its two instruments in Europe - NATO and the EU. After two strong waves of the post-Cold War expansion to four countries in 1999 and seven countries in 2004, NATO was strategically stopped on the western borders of the former Soviet republics of Belarus, Ukraine and Moldova, with minimal, almost no chance of continuing the campaign. Over the next decade and a half, it has succeeded to successively include only four other small Balkan countries, which are, however, only of lower importance Croatia and Albania in 2009, Montenegro in 2017 and North Macedonia in 2020 - largely due to the creation, instrumentalizing and forcing of their anti-Serb role. ${ }^{2}$ Precisely for these reasons, it can hardly be expected that it will legally and legitimately include Serbia and $\mathrm{BiH}$ (due to the resistance of the Republic of Srpska) and thus finish the unfinished business in the Balkans. At the same time, the US's ties as "commander-in-chief" with "subordinates" are increasingly problematic, and the mutual relations of the allies are often antagonistic to the point of mutual conflict. Aren't these two

\footnotetext{
${ }^{2}$ In the then FYR Macedonia, there was even a referendum held with the question: "Are you for the EU and NATO membership, with the acceptance of a name compromise between the Republic of Macedonia and the republic of Greece?", which failed due to a massive boycott (only 37\% voted). That means that it wasn't only the state's name change that was rejected, but also its ascension into the euroatlantic organizations. In spite of the people's obvious opposition shown, the country was incorporated into the NATO!
} 
examples, each in its own way, indicative "litmus tests" of the crisis of Atlanticism - one, the refusal of members to finance the Alliance with the "prescribed percentage" of GDP and the other, the constant tension on the so-called Southern wing between two important members Greece and Turkey - which this time (at the end of July 2020) was on the brink of war near the island of Megisti (Kastellorizo)?

And when the USA and NATO are weak, according to the principle of geopolitical "connected vessels", the EU is also weak. From the point of view of the West, this seems apocalyptic because it indicates a "crack in the monolith". The president of France, one of the key members of both organizations, warned about this in an interview given to a prominent Economist on October 21, 2019 (published on November 7, 2019) - on the exact year when NATO marked the 70th anniversary. Stating that 'what we are currently experiencing is NATO's brain death', which is why the EU is on the 'edge of a precipice', and that it is high time to 'wake up' because otherwise 'it will no longer be in control of our destiny' (Macron, 2019), he did give a diagnosis and possible consequences of the latent dysfunctionality of Western integrations but did not take into account the initial, essential, so-called construction error. The genuine causes of the crises are more adequately pointed out by the act of leaving of the one EU's so-called old member, with great demographic, territorial, military, political, and economic "specific weight" - Brexit. The fact that this will not be an exception in the European wing of the Atlanticist camp, but a hard-to-stop trend of disunity, has long been manifested by the different approaches of the individual or groups of members on the occasion of almost every crisis, such as the long-standing issue of immigrants. Even the existential threat of the COVID 19 pandemic did not contribute to the "closing of ranks", an increase of solidarity and joint struggle. On the contrary! It started literally by snatching the necessary medical equipment and leaving Italy and Spain to themselves and came to a barely reached compromise in the EU between the "leading two" (Germany and France), the "thrifty four/five" (Austria, Denmark, the Netherlands, Sweden, joined by Finland) and the "prodigals" (other members) on the adoption of the EU draft budget for 2021-2027. Although it has been proposed that as much as €750 billion should be earmarked for post-pandemic economic recovery, the enigma remains whether the amount will be adopted by the European Parliament by the end of 2020 and how it will be achieved - most likely by even higher borrowing 
and additional taxation ( $€ 390$ billion non-refundable and 360 billion in lowinterest loans) (European Council, 2020, p. 3).

Opposite the Empire of countries and organizations under the USA leadership, which is obviously in a far advanced process of the relative weakening, there is an increasingly strong Eurasian "community of giants". China and Russia are convincingly in the lead among them, striving to achieve the widest and most diverse alliances. Global confrontation is fierce and is taking place in all fields, with the exception of direct armed conflict for now, but also involving brutal hybrid and network warfare. It is not just a mere struggle to take over the world throne, but a change in the global geopolitical paradigm and a completely new concept of (super) power. More precisely, it is not just a question of transforming the thalassocratic Atlanticist unipolar "new world order" into the tellurocratic Eurasian multipolar "even newer world order". For the world, the establishment of a "new bipolarism" is forthcoming, based on the integral power of the so-called full spectrum. On its two sides, there will be "integration clusters" based on different, selective, and flexible principles and factors - geographical, civilizational, communication, military security, political, economic. The actual clash of the "big players" has already been projected on the "Balkan subcontinent" as one of the crucial geopolitical regions, primarily on its fragmented post-Yugoslav part. The Balkan "indicators of new bipolarism" are Kosovo and Metohija, based on which the whole world allied either as a pro-Atlanticist or anti-Atlanticist (Степић, 2018, p. 42). It is the Balkans, which in the post-Cold War period was structured in accordance with Western, Atlanticist postulates, that will be the subject of interest and fundamental rearrangement in accordance with Eurasian principles. The place of the previous regional "subcontractors of geopolitical works" in the name of Washington, London, Berlin, Vienna, logically should be taken by the exponents of Beijing and Moscow as the coming forces. The continuous destabilization of the Balkans for three decades, caused by the Atlanticist engagement in the violent disintegration of the SFRY, and whose best evidence is the inconsistent borders of the new states, can only be completed by their adequate redefinition in Eurasian direction. In the conditions of increasingly offensive Eurasianism, whose geopolitical and geoeconomic Balkan vectors are (also) projected through Serbian countries, the persistent Serbian pro-Western orientation is obviously becoming a counterproductive dogma that requires re-examination. 


\section{Geopolitical duality of Eurasianism and the Serbian position}

Atlanticism is a multidimensional concept of the world order, but in the geopolitical sense it is unambiguous:

- it is theoretically designed and practically implemented monistically by one, the inviolable superpower of the West, the USA;

- The USA based it on a single, thalassocratic geopolitical principle, drawing from it the total, global power;

- it was implemented by controlling Eurasia through its one, peripheral macro-entity - Rimland;

- the ultimate goal was the establishment and duration of a globalist unipolar order, i.e., of a world under USA "constant leadership" (Pax Americana).

On the other hand, Eurasianism is pluralistic in all dimensions, and also geopolitical:

- in the current historical "cross-section", it is personified by two powers

- Russia and China - with a realistic perspective that, at a lower, macroregional level, more of them will join them;

- initially, it was founded tellurocratically, but in modern variants, it also develops on other principles, i.e., more and more as an integral conception;

- it creates the future world order as multi-polar (polycentric), with the possibility to eventually move to a balanced hierarchical model of neobipolarism;

- joining to the integration is not based on coercion, unanimity and unification, but on voluntariness, symbiosis of interests and multidimensional pluralism - ideological-political, economic, culturalcivilizational;

- Anti-Atlanticism and the expulsion of the USA from Eurasia are key factors on which the cohesion of as many Asian, African, Latin American and even European countries as possible is based;

- delicate relations and conflicting historical heritage within heterogeneous Eurasia seeks to overcome with as little conflict as possible and in a multilateral way, especially by trying to coexist with 
the expanding Islamic world, and by constructively controlling potentially destructive EU-Russia and India-China rivalries.

Although the Russian and Chinese Eurasian concepts have great similarities, a common "red thread", and for now they are largely complementary, they differ in nature. This is recognizable based on two phenomena that personify them - the Eurasian Economic Union (EAEU) and the Belt and Road Initiative (BRI). The Russian thinker Leonid Savin understood this difference: '...The Eurasian Economic Union (EAEU) is really an integration project, and the Chinese BRI is not. China is interested in connection, not integration' (Савин, 2019, p. 49). Russian neo-Eurasianism represents the Eurasian idea of "white" emigrant intellectual circles from the 1920s/30s, adapted to modern conditions. It identifies Russia as a multidimensional, and especially cultural-geographical predetermined center of a gathering of other great partners on the largest mainland on the Planet (Вуковић, 2013, p. 108). It also has an emphasized spatial dimension in the sphere of neoclassical geopolitics. It implies the territorialization of global political relations, and the phased division of the world into several meridians elongated pan-zones and several large spaces in their composition, all in accordance with the initial postulates of continentalism and multi-polarism.

The realization of the neo-Eurasian (re) composition of the world is predicted through the 'axis of friendship' (Дугин, 2009, p. 113), i.e., the geopolitical vectors directed towards several key countries and regions the three basic (two plus one) towards Germany and Japan/China, and the Islamic world, and several auxiliary to Indochina, South Asia, the Middle East and even some areas outside Eurasia such as the Caribbean (Степић, 2013, pp. 107-108). In the early neo-Eurasian variants, the vector towards the Balkans was omitted, although it is a region of first-class importance for achieving the world power and "taking over" Europe from Atlanticist hands (Степић, 2014b, pp. 120-127). Undoubtedly the most suitable starting point for the Balkan "axis of friendship" is the Serbian lands, which is respected in some revised views (Дугин, 2004, p. 200), and therefore the Serbian factor (Belgrade) is assigned an important geopolitical role of one of the four centers of phased neo-Eurasian integration. (Панарин, 2012).

The intensive modern development and expansion of China have long been challenged by geopolitics. China insisted on cooperation in the framework of the economy, finance, trade, communications, new 
technologies, and other "benign" aspects of connection, so as not to provoke resistance from other forces. However, in the Chinese so-called charm offensive can be clearly recognized the specific features of Eurasianism and postmodern geopolitics. Moreover, 'China is striving to become the first power in history to build an integral geopolitical code and power - both telurocratic and thalassocratic at the same time' (Зарић, 2013, p. 200). China embarked on a major campaign many years before she announced in 2013 first the idea of a (land) Silk Road Economic Belt, and then the 21st Century Maritime Silk Road. Thus, the networking of the Afro-Eurasian mainland and the broad coastal zone started to be globally recognized by the abbreviation OBOR (One Belt One Road), and then the BRI (Belt and Road Initiative). For the vectors of Chinese Eurasianism and their westward penetration, the Central Asian "five" are of key mediating importance. It now successfully corresponds to the earlier American formula $\mathrm{C} 5+1$ with the counter-formula C+C5 (China plus Kazakhstan, Uzbekistan, Tajikistan, Kyrgyzstan, and Turkmenistan). It also uses the CPEC formula (China-Pakistan Economic Corridor) for land access to the Indian Ocean basin, from where it can "keep an eye" on the strategically important Strait of Hormuz and establish "threads" that connect it with oil giants Iran, Saudi Arabia, and the United Arab Emirates.

At the same time, China continues multiplying its Eurasian connections by initiating the Arctic Silk Road (activating the Northern Sea Route together with Russia), the Digital Silk Road (for cross-border e-commerce), and the Medical Silk Road (for medical assistance due to COVID-19). For countries whose poverty will accelerate sharply in the post-pandemic period, borrowing from China is becoming the only way out, which China already "charges" by dragging them into its orbit by privileged business positions, gaining territorial concessions, and positioning at strategic points. China is largely accused by its competitors for using 'debt-trap diplomacy' (Engdahl, 2020). All this confirms that the comprehensive Silk (geopolitical) concept (Stepić, Zarić, 2016, p. 452) will be difficult to stop by USA sanctions, a real economic and propaganda war, and the increasingly ambitious attempts to form an anti-Chinese coalition in the world level. The full realization of the Silk (geopolitical) concept - as well as the success of Russian neoEurasianism - depends on the penetration into Europe, in which the Balkans is crucial. It is an integral part of the China+17 initiative, which has the characteristics of the Baltic-Aegean intermarium "vertical", geopolitically 
similar to the buffer Sanitary cordon from a century earlier. But, for the sake of certain success, China will also need an intermarium "horizontal" - the Black Sea-Adriatic one - with a point of intersection in Belgrade (Stepić, Zarić, 2016, pp. 460-461). Therefore, China is focusing on the Serbian factor, which qualifies as a key regional mediator because of its central geographical position and anti-Atlanticist geopolitical orientation.

\section{Instead of conclusion: Serbian benefits from Russian and/or Chinese Eurasianism}

It is not excluded that the complementarity of two modern Eurasianisms - Russian and Chinese - will last only until the ousting of a great common rival, and after that, it will grow into direct rivalry, competition for influence, and even confrontation in Eurasia and the world as a whole. On the contrary, it is possible to continue their peaceful coexistence with the "smallest common denominator" of geopolitical, geoeconomic and other interests, and with some form of division of areas of activity and zones of responsibility. The multidimensional heterogeneity of Eurasia is a suitable environment for the emergence and development of still relatively autonomous, limited, partial variants of Eurasianism of macroregional and transregional ranges, which will difficult fit into the previous two main streams. These can be Indian subcontinentalism in South Asia and the Indian Ocean basin, Turkish neo-Ottomanism and pan-Turkism in parts of the Balkans, Central and Western Asia, Iranian Islamist (mostly Shiite) fundamentalism in the Gulf, Southwest and also Central Asia, Indonesian Indo-Pacific Trans-oceanism in Southeast Asia, Saudi expansionist Wahhabism, and even pan-Arabism in the Middle East, German Mitteleuropeanism extended from Central to Eastern and especially to Southeastern Europe, and so on.

In the Balkans, through NATO and the EU, Atlanticism is still dominant, but its "offer" is less and less attractive. On the other hand, Eurasianism is more and more present on the Balkan "subcontinent", and it is especially attractive from the point of view of Serbian national interests. Preserving Serbia's sovereignty in the face of direct Atlanticist attacks aiming to separate its Kosovo-Metohija part is only an obvious indicator. Much more important are the essential reasons for Serbia's closeness to Eurasianism, 
primarily Russian neo-Eurasianism, which are geographical, historical, ethnical, cultural-civilizational, geopolitical, geoeconomic and others. Therefore, the Serbian factor can become a key guarantor of the 'neoEurasian Balkan sub-order' (Степић, 2017b, p. 25), as evidenced by the socalled strategic partnership between Russia and Serbia. It is reflected in the procurement of Russian weapons for the Serbian Army, the pipeline route of the former South and now Turkish Stream, the sale of NIS to Gazpromneft, Russian investments in Serbian roads, and especially the Free Trade Agreement between Serbia and the EAEU. This agreement was not signed with any other European country, and it opens the possibility of Serbian exports to a market of almost 200 million people (the Russian government approved ratification on July 26,2020 ).

Due to its position as a central, transit, hub and non-Atlanticist country, Serbia is the most suitable mediator for China's Eurasian BRI-influence in the Balkans. For now, geoeconomics is a "visible part of the spectrum" of the rapid growth of Chinese influence, as evidenced by credit arrangements, investment in Serbia's infrastructure, buying of strategic companies (the ironworks in Smederevo, RTB Bor, etc.), investment in new technologies and reindustrialization, but also increasingly significant deliveries of modern Chinese weapons. The Republic of Srpska is intensively involved in similar flows (e.g., the Russian purchase of the refinery in Brod, the Chinese construction of TPP Stanari, etc.). In the current situation, Chinese and Russian Eurasianism competitors in the Balkans, but it might not remain their (longlasting) relationship. If (When?) these two expanding powers conduct deAtlantization of the Balkans, the question is whether they will start fighting each other for supremacy? Will the Serbian choice follow at some point no longer the West or the East, but Russian or Chinese Eurasianism? Will Russia and China continue to support the independence of the states - even small Balkan ones - for which they are currently advocating, or will they keep and even more sharply implement the concept of limiting and usurping parts of their sovereignty? Can they, one and/or the other, realize their interests to the maximum if they inherit the current Atlanticist geopolitical configuration of the Balkans, or will they overcome its dysfunction by recomposing the borders, primarily the post-Yugoslav ones? 


\section{References}

Bžežinski, Z. (2001). Velika šahovska tabla. Podgorica, CID; Banja Luka, Romanov.

Вуковић, Н. (2013). Геокултурни аспекти евроазијства у делу Александра Панарина, у: Миломир Степић, Живојин Ђурић (ур.), Србија и евроазијски геополитички простор (стр. 105-126). Београд, Институт за политичке студије,

Дугин, А. (2004). Основи геополитике 1. Зрењанин, Екопрес.

Дугин, А. (2009). Геополитика постмодерне. Београд, Преводилачка радионица „Росић“; ИКП „Никола Пашић“.

Engdahl, W. (2020, June 1). Can China Silk Road Survive Coronavirus?, retrieved from https://journal-neo.org/2020/06/01/can-china-silkroad-survive-coronavirus/. Accessed 7 August 2020.

Зарић, И. (2013). Евроазијска геополитичка и геостратегијска перспектива Народне Републике Кине, у: Миломир Степић, Живојин Ђурић (ур.), Србија и евроазијски геополитички простор (стр. 195-230). Београд, Институт за политичке студије.

Macron, E. (2019, November 7). Emmanuel Macron warns Europe: NATO is becoming brain-dead, The Economist (Interview), retrieved from https://www.economist.com/europe/2019/11/07/emmanuel-macron -warns-europe-nato-is-becoming-brain-dead. Accessed 29 July 2019.

Над, Б. (2020, Јун 5). Зашто Запад (више) није изузетан. Печат, бр. 618, стр. 53.

Панарин, И. Н. (2012). СМИ, пропаганда и информационные войны. Москва, Поколение. (7.5. „Вторая мировая информационная война и интеграция Евразии“), retrieved from www.propagandahistory.ru/ books/Igor-Panarin_SMI-propaganda-i-informatsionnye-voyny/45, Accessed 5 August 2020.

Пандуревић, В. (2018). Нови хладни рат и Србија. Београд, Представништво Републике Српске; Свет књиге.

Савин, Л. (2019, October 25). Нека Трамп поново учини Америку великом. Печат, бр. 591, стр. 49.

Степић, М. (2013). Геополитика неоевроазијства - позиција српских земаља. Београд, Институт за политичке студије. 
Степић, М. (2014а). Српски парадокс: национална дезинтеграција као услов супранационалне интеграције. у: Зоран Милошевић, Живојин Ђурић (ур.), (Дез)интеграција држава и идентитет (стр. 153-176). Београд, Институт за политичке студије.

Степић, М. (2014б). Балкан - недостајуће исходиште неоевроазијског вектора, Српска политичка мисао, 2/2014, стр. 111-131.

Stepić, M.; Zarić, I. (2016). Serbia and Geopolitical (non)Complementarity of the Danube strategy and the New silk road. in: Duško Dimitrijević (ed.), Danube and the New Silk Road (pp. 447-466).Belgrade, Institute of International Politics and Economics.

Степић, М. (2017а). Од (нео)класичних ка постмодерним геополитичким постулатима. у: Миломир Степић (ур.). Свет и нове геополитичке парадигме (стр. 13-36). Београд, Институт за политичке студије.

Степић, М. (2017б). Деатлантизацијом до стабилизације Балкана: српски национални интерес, Национални интерес, 1/2017, стр. 9-37.

Степић, М. (2018). Косово и Метохија као индикатор новог биполаризма. Српска политичка мисао, 3/2018, стр. 27-49.

European Council (2020), Special meeting of the European Council /Conclusions/, General Secretariat of the Council, Brussels, 2020, July 21 p. 3; retrieved from: https://www.consilium.europa.eu/media/ 45109/210720-euco-final-conclusions-en.pdf, Accessed 26 July 2020.

Трифковић, С. (2017). Континуитет хладног рата. Београд, Геополитика. https://www.worldometers.info/coronavirus/country/ us/Accessed 16 August 2020. 